\title{
Skuteczność i bezpieczeństwo stosowania trabektedyny w leczeniu pacjentów, u których rozpoznano zaawansowane tłuszczakomięsaki i mięśniakomięsaki gładkokomórkowe (L-mięsaki)
}

\author{
Hanna Koseła-Paterczyk, Katarzyna Kozak, Anna Klimczak, Tomasz Świtaj, Piotr Rutkowski
}

Wstęp. Trabektedyna jest lekiem zarejestrowanym do leczenia chorych z rozpoznaniem zaawansowanych mięsaków tkanek miękkich. Badania wykazały jej skuteczność w leczeniu paliatywnym, zwłaszcza w tłuszczakomięsakach (LPS - liposarcoma) i mięśniakomięsaku gładkokomórkowym (LMS - leiomyosarcoma). Celem badania była analiza wyników leczenia trabektedyną pacjentów leczonych w jednym ośrodku.

Materiały i metody. Od kwietnia 2008 roku do października 2013 roku leczono trabektedyną 50 pacjentów (23 kobiety, 27 mężczyzn) z rozpoznaniem miejscowo zaawansowanych przerzutowych mięsaków tkanek miękkich (20 — LMS, 30 - LPS, w tym 13 myxoid LPS - MLPS). Mediana wieku w momencie leczenia wyniosła 51 lat. Prawie wszyscy chorzy (49/50) otrzymali wcześniejsze leczenie systemowe oparte na doksorubicynie. 14 (28\%) pacjentów otrzymywało trabektedynę w 2. linii leczenia, 23 (46\%) w 3. linii, 13 (26\%) w > 3. linii. Odpowiedź na leczenie według kryteriów RECIST oceniano co 3 miesiące za pomocą badania tomografii komputerowej (CT).

Wyniki. Mediana liczby podanych cykli leczenia wynosiła 5 (zakres 2-40); 18 chorych (36\%) otrzymało $\geq 10$ cykli. U 4 pacjentów (8\%) stwierdzono częściową odpowiedź, u 23 (46\%) stabilizację choroby (przez minimum 3 miesiące), u 23 (46\%) - progresję choroby. Po pół roku leczenia 47\% pacjentów było wolnych od progresji choroby (PFS — progression-free survival), więcej w grupie chorych z rozpoznaniem LPS - 66\% w porównaniu z $27 \%$ w grupie LMS ( $p=0,023$ ). PFS był istotnie dłuższy u pacjentów otrzymujących trabektedynę $w 2$. lub 3. linii leczenia (mediana 7 miesięcy) niż > 3. linii leczenia (mediana 2 miesiące) $p=0,038$. Mediana przeżycia całkowitego (OS — overall survival) wynosiła 13 miesięcy. Stężenie hemoglobiny oraz aktywność LDH przy rozpoczęciu leczenia nie miało wpływu na wyniki terapii. 34 pacjentów otrzymało kolejne linie leczenia po niepowodzeniu leczenia trabektedyną. W momencie analizy 37 chorych zmarło. Podtyp histologiczny miał wpływ na OS ( $p=0,008)$, prawie $70 \%$ pacjentów z rozpoznaniem MLPS żyło dłużej niż rok. Toksyczność terapii była umiarkowana. Nie obserwowano zgonów spowodowanych leczeniem. 30 (60\%) pacjentów doznało jakiejkolwiek toksyczności leczenia, w większości w stopniu 1. i 2. Trzech pacjentów wymagało redukcji dawki leku.

Wnioski. Przeprowadzona analiza potwierdza skuteczność stosowania trabektedyny w paliatywnym leczeniu u chorych na L-mięsaki. Zastosowanie leku pozwala na uzyskanie długotrwałej kontroli choroby przy dobrej tolerancji leczenia. Najdłuższy czas całkowitego przeżycia stwierdzono w grupie chorych z rozpoznaniem MLPS.

\section{The efficacy and safety of trabectedin in patients with advanced liposarcomas} and leiomyosarcomas (L-sarcomas)

Introduction. Trabectedin is a novel drug approved for the treatment of patients with advanced soft tissue sarcoma. It shows activity especially in the palliative treatment of liposarcomas (LPS) and leiomyosarcoma (LMS). The aim of this work was to analyze the results of treatment with the use of trabectedin in one oncology center.

Materials and methods. From April 2008 to October 2013, 50 patients ( 23 women, 27 men) with metastatic/locally advances L-sarcomas have been treated with trabectedin. Pathological diagnosis were as follows: 20 leiomyosarcoma 
(LMS), 30 liposarcoma (LPS) — including 13 myxoid LPS (MPLS). Median age at treatment start was 51 years. Nearly all patients had previous chemotherapy based on doxorubicin. 14 (28\%) patients received trabectedin in second line of treatment, 23 (46\%) in third line, $13(26 \%)$ in > third line of treatment. Responses to treatment were evaluated every 3 months by computed tomography imaging according to RECIST 1.1 criteria.

Results. Median of received cycles of treatment is 5 (range 2-40); 18 patients (36\%) received $\geq 10$ cycles. 4 patients (8\%) had partial response according to RECIST, 23 (46\%) had stable disease, 23 (46\%) had progressive disease. After 6 months $47 \%$ of the patients were free from disease progression, more in the LPS group - $66 \%$ than in LMS group $-27 \% p=0,023$. Progression free survival (PFS) was significantly longer in patients receiving trabectedin in 2 . or 3. (median 7 months) line than $>$ third line of treatment (median 2 months) $p=0,038$. Median overall survival (OS) is 13 months with 37 patients died at the time of analysis. Neither hemoglobin level nor LDH level at the start of treatment had impact on the results. 34 patients after progression received next line chemotherapy. Histology had impact on OS ( $p=0.008)$, almost $70 \%$ of patients with MLPS lived longer than a year. Toxicity was moderate. $30(60 \%)$ patients had some kind of treatment toxicity, in majority grade 1 or 2 . Three patients required dose reductions.

Conclusion. Our analysis confirms efficacy and safety of trabectedin in patients with advanced L-sarcomas. Use of the drug give possibility for long lasting control of the disease with good tolerance of the treatment. The longest overall survival could be observed in patient with the diagnosis of myxoid liposarcoma.

NOWOTWORY Journal of Oncology 2015; 65, 6: 451-457

Słowa kluczowe: trabektedyna, przerzutowe mięsaki tkanek miękkich, tłuszczakomięsaki myksoidne, mięśniakomięsaki gładkokomórkowe

Key words: trabectedin, metastatic soft tissue sarcoma, myxoid liposarcoma, leiomyosarcoma

\section{Wstęp}

Mięsaki tkanek miękkich (MTM) to rzadko występujące nowotwory złośliwe, tworzące niejednorodną i złożoną grupę o różnym stopniu różnicowania mezenchymalnego. Stanowią one około 1\% wszystkich nowotworów złośliwych [1]. Roczna zachorowalność na MTM wynosi ok. 3 przypadki na 100 000. W Polsce w 2012 roku MTM rozpoznano u 706 pacjentów, 407 osób zmarło z tego powodu [2].

MTM są nowotworami o złym rokowaniu, u około $50 \%$ pacjentów dochodzi do powstania zmian przerzutowych. Ich najczęstszą lokalizacją są płuca. Mediana czasu przeżycia u pacjentów z rozpoznaniem MTM w przypadku rozpoznania nieresekcyjnych przerzutów wynosi około 12 miesięcy [3]. Obecnie standardowym postępowaniem w przypadku rozpoznania MTM w stadium choroby przerzutowej jest zastosowanie chemioterapii opartej na doksorubicynie i/lub ifosfamidzie. Zastosowanie tych chemioterapeutyków pozwala na uzyskanie odsetka odpowiedzi na leczenie od około $15 \%$, jeśli stosowane są one w monoterapii, do około $30 \%$, gdy leki te stosowane są w kombinacji [4]. W ostatnich latach ukazały się wyniki szeregu badań nad nowymi lekami w leczeniu pacjentów z rozpoznaniem zaawansowanych MTM. Wyniki badań nad skutecznością i bezpieczeństwem zastosowania trabektedyny zaowocowały rejestracją tego leku i jego wejściem do powszechnego użytku.

Trabektedyna (nazwa handlowa Yondelis) jest alkaloidem uzyskiwanym pierwotnie z osłonicy Ecteinascidia turbinata. Lek przyłącza się do mniejszego rowka helisy DNA, jego aktywność biologiczna następuje poprzez modulację czynników transkrypcyjnych i interakcje z białkami odpowiedzialnymi za naprawę DNA [5]. Skuteczność trabektedyny w paliatywnym leczeniu pacjentów z rozpoznaniem przerzutowych/nieresekcyjnych MTM udowodniono w trzech badaniach klinicznych drugiej fazy i jednym badaniu trzeciej fazy, do których włączani byli pacjenci po niepowodzeniu wcześniejszych linii leczenia [6-9], oraz u chorych nieleczonych wcześniej systemowo [10]. Opublikowano także szereg danych pochodzących z rozszerzonego dostępu do tego leku [11-13]. Badanie rejestracyjne leku przeprowadzono na grupie pacjentów z rozpoznaniem tzw. L-mięsaków (Liposarcoma — LPS i Leiomyosarcoma - LMS) po niepowodzeniu wcześniejszych linii chemioterapii. Chorych włączono losowo w stosunku 1:1 do grupy otrzymującej lek we wlewie dobowym co 21 dni albo we wlewie 3-godzinnym co tydzień przez 3 tygodnie 4-tygodniowego cyklu. W badaniu wykazano większą skuteczność przy stosowaniu schematu z wlewem dobowym, przy nieznacznie większej toksyczności. U chorych leczonych schematem 24-godzinnym, w porównaniu z drugim schematem, stwierdzono dłuższą medianę PFS: 3,3 miesiąca vs 2,3 miesiąca (HR 0,755; 95\% Cl 0,574-0,992), a także dłuższą medianę OS: 13,9 miesiąca vs 11,8 miesiąca. Lepszy też był odsetek obiektywnych odpowiedzi: 5,6\% vs 1,6\% [14]. W 2015 roku przedstawiono wyniki wieloośrodkowego badania III fazy, gdzie porównano skuteczność trabektedyny (podawanej w dawce $1,5 \mathrm{mg} / \mathrm{m}^{2}$ przez 24 godziny co 3 tygodnie) $z$ dakarbazyną (w dawce $1 \mathrm{~g} / \mathrm{m}^{2}$ co 3 tygodnie) w leczeniu 518 chorych na zaawansowane L-mięsaki (liposarcoma i leiomyosarcoma) 
w minimum III linii terapii. Zaprezentowano wyniki dla drugorzędowego punktu końcowego, wykazując poprawę PFS dla ramienia $z$ trabektedyną $w$ porównaniu z dakarbazyną - mediana PFS wyniosła 4,2 versus 1,5 miesiąca (iloraz hazardu, $[H R]=0,550 ; p<0,0001)$, długość trwania odpowiedzi również była większa dla trabektedyny niż dla dakarbazyny ( $H R=0,471, p=0,1415$; mediana $=6,5$ vs 4,2 miesiąca). Przy leczeniu trabektedyną stwierdzono zmniejszenie o $45 \%$ względnego ryzyka zgonu lub progresji choroby [9]. Badanie to potwierdziło skuteczność trabektedyny u chorych na zaawansowane L-mięsaki.

Wyniki tego pierwszego badania stały się podstawą do rejestracji trabektedyny w Unii Europejskiej, w tym i w Polsce. W naszym kraju lek dostępny jest w ramach programu lekowego Narodowego Funduszu Zdrowia od 2011 roku do stosowania u pacjentów z rozpoznaniem zaawansowanych LPS lub LMS (L-mięsaków) po niepowodzeniu leczenia antracyklinami i ifosfamidem lub u pacjentów niekwalifikujących się do leczenia tymi lekami. Wcześniej trabektedynę stosowano w ramach chemioterapii niestandardowej w tych samych wskazaniach. Celem poniższej pracy jest analiza wyników leczenia trabektedyną i bezpieczeństwo stosowania tego leku u pacjentów leczonych w Klinice Nowotworów Tkanek Miękkich, Kości i Czerniaków (KNTMKiCz) Centrum Onkologii — Instytutu w Warszawie.

\section{Materiał i metody}

Do tej retrospektywnej analizy włączono 50 pacjentów (23 kobiety, 27 mężczyzn) leczonych paliatywnie trabektedyną w KNTMKiCz z powodu zaawansowanych nieresekcyjnych LMS lub LPS w czasie od kwietnia 2008 do października 2013. Mediana wieku w momencie leczenia wyniosła 51 lat (zakres 26-76 lat). Szczegółowa charakterystyka pacjentów znajduje się w tabeli I.

Trabektedyna podawana była w 24-godzinnych wlewach przez port naczyniowy w dawce $1,5 \mathrm{mg} / \mathrm{m}^{2}$ w cyklach co 21 dni. Jako profilaktykę przeciwwymiotną podawano ondansetron oraz deksametazon (który oprócz działania przeciwwymiotnego ma udowodniony wpływ na zmniejszenie odsetka występowania toksyczności wątrobowej trabektedyny [15]). Odpowiedź na leczenie według kryteriów RECIST 1.1 oceniano co 3 miesiące za pomocą badania CT. Obliczenia statystyczne przeprowadzono z zastosowaniem pakietu oprogramowania R 2.11 (R Development Core Team 2010). Krzywe przeżycia, medianę czasu przeżycia z przedziałem ufności oszacowano metodą Kaplana-Meiera. Czas przeżycia całkowitego (OS) został obliczony od daty rozpoczęcia leczenia trabektedyną do daty ostatniej obserwacji lub zgonu. Czas wolny od progresji choroby (PFS) został obliczony od daty rozpoczęcia leczenia trabektedyną do daty ostatniej obserwacji lub udowodnionej radiologicznie progresji choroby. Mediana czasu obserwacji wynosiła
Tabela I. Charakterystyka pacjentów

\begin{tabular}{|c|c|c|}
\hline Charakterystyka pacjentów $(n=50)$ & $\begin{array}{c}\text { Liczba } \\
\text { pacjentów }\end{array}$ & $\%$ \\
\hline \multicolumn{3}{|l|}{ Płeć: } \\
\hline żeńska & 23 & 46 \\
\hline męska & 27 & 54 \\
\hline \multicolumn{3}{|l|}{ Podtyp histologiczny: } \\
\hline LMS & 20 & 40 \\
\hline LPS & 30 & 60 \\
\hline (myxoid LPS — MLPS) & 13 & 26 \\
\hline \multicolumn{3}{|l|}{$\begin{array}{l}\text { Wcześniejsze linie chemioterapii } \\
\text { z zastosowaniem: }\end{array}$} \\
\hline doksorubicyny & 49 & 98 \\
\hline ifosfamidu & 18 & 36 \\
\hline \multicolumn{3}{|l|}{ Trabketedynę stosowano w: } \\
\hline 2. linii leczenia & 14 & 28 \\
\hline 3. linii leczenia & 23 & 46 \\
\hline w $>3$. linii leczenia & 13 & 26 \\
\hline \multicolumn{3}{|l|}{ Zaawansowanie choroby: } \\
\hline izolowane przerzuty do wątroby & 3 & 6 \\
\hline izolowane przerzuty do płuc & 12 & 24 \\
\hline $\begin{array}{l}\text { miejscowe zaawansowanie choroby } \\
\text { (nieresekcyjny nowotwór) }\end{array}$ & 17 & 34 \\
\hline rozsiew wielonarządowy & 18 & 36 \\
\hline \multicolumn{3}{|l|}{$\begin{array}{l}\text { Czas od pierwotnego rozpoznania MTM } \\
\text { do rozpoczęcia leczenia trabektedyną: }\end{array}$} \\
\hline 0-12 miesięcy & 7 & 14 \\
\hline 12-24 miesięcy & 8 & 16 \\
\hline > 24 miesięcy & 35 & 70 \\
\hline \multicolumn{3}{|l|}{ Wyjściowe stężenie hemoglobiny: } \\
\hline w normie & 32 & 64 \\
\hline poniżej normy & 18 & 36 \\
\hline \multicolumn{3}{|l|}{$\begin{array}{l}\text { Wyjściowa aktywność dehydrogenazy } \\
\text { mleczanowej (LDH): }\end{array}$} \\
\hline w normie & 25 & 50 \\
\hline powyżej normy & 25 & 50 \\
\hline
\end{tabular}

22 miesiące. Działania niepożądane leczenia oceniane były według kryteriów CTC (Common Toxicity Criteria) wersja 4.

\section{Wyniki}

Mediana liczby cykli leczenia wynosiła 5 (zakres 2-40), 18 chorych (36\%) otrzymało $\geq 10$ kursów leczenia. U żadnego pacjenta nie uzyskano całkowitej odpowiedzi na leczenie (CR), u 4 pacjentów (8\%) stwierdzono częściową odpowiedź na leczenie (PR), 23 (46\%) stabilizację choroby (SD) $\geq 3$ miesięcy, u 23 (46\%) - progresję choroby (PD). Ponad połowa pacjentów (54\%) miała korzyść kliniczną z leczenia (PR+SD) (ryc. 1). Mediana PFS wyniosła 3 miesiące. Po pół roku le- 


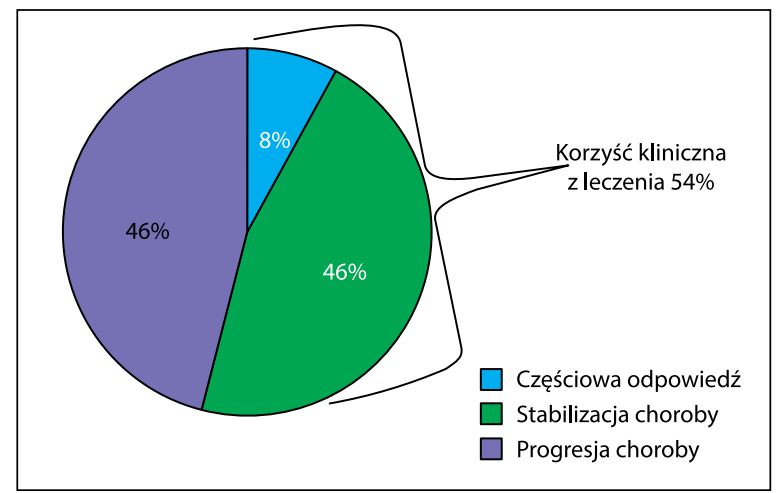

Rycina 1. Odpowiedź na leczenie

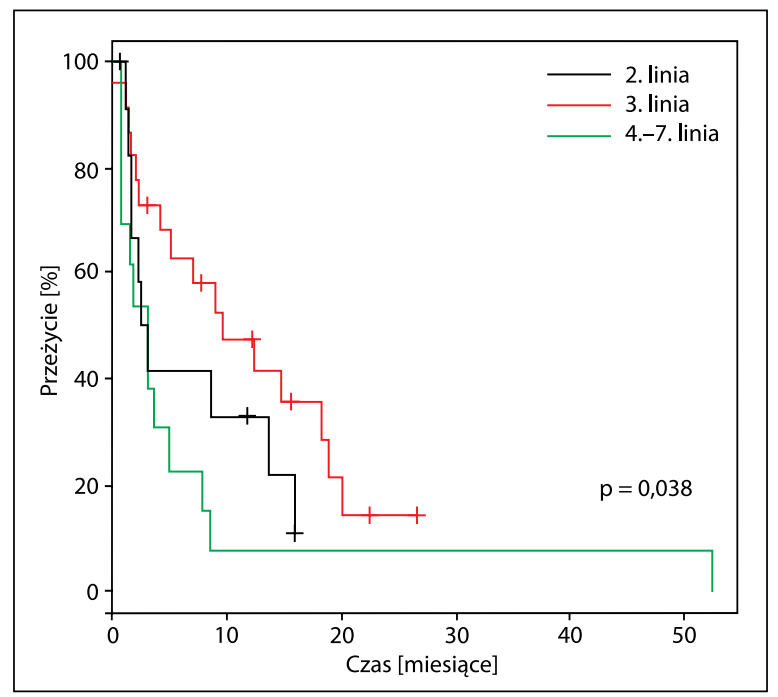

Rycina 2. PFS w zależności od tego, w której linii leczenia stosowano trabektedynę

czenia $47 \%$ pacjentów było wolnych od progresji choroby, więcej w grupie chorych z rozpoznaniem LPS - 66\% w porównaniu z 27\% w grupie LMS ( $p=0,023)$. PFS był istotnie dłuższy u pacjentów otrzymujących trabektedynę w 2. lub 3. linii (mediana PFS w tej grupie to 7 miesięcy) niż $>3$ linii leczenia (mediana PFS $w$ tej grupie to 2 miesiące) $p=0,038$ (ryc. 2). Mediana OS wyniosła 13 miesięcy. Dwa lata od rozpoczęcia leczenia przeżyło $27 \%$ pacjentów. Podtyp histologiczny miał wpływ na OS ( $p=0,008$ ): 70\% pacjentów z rozpoznaniem MLPS żyło dłużej niż rok (ryc. 3). Na wyniki leczenia wpływ miała też dynamika choroby. Lepsze rokowanie zarówno w przypadku PFS, jaki OS (odpowiednio $p=0,058 \mathrm{i} p=0,005$ ) stwierdzono w grupie chorych, u których rozpoczęto leczenie trabektedyną ponad dwa lata od pierwotnego rozpoznania MTM, w porównaniu z tymi chorymi, u których przebieg choroby był krótszy (ryc. 4 i 5) Stopień zaawansowania choroby ani lokalizacja zmian przerzutowych nie miały istotnego wpływu ani na PFS, ani na OS

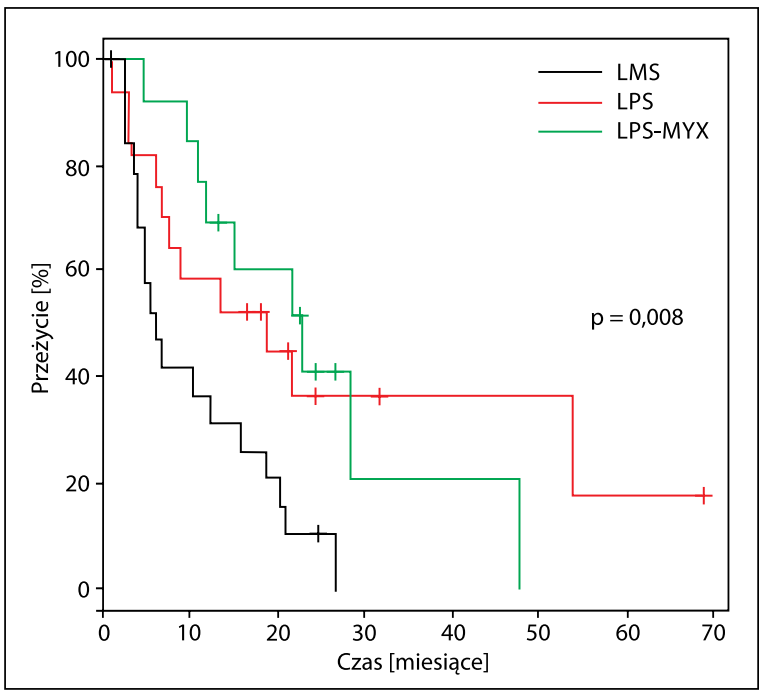

Rycina 3. OS w zależności od podtypu histologicznego

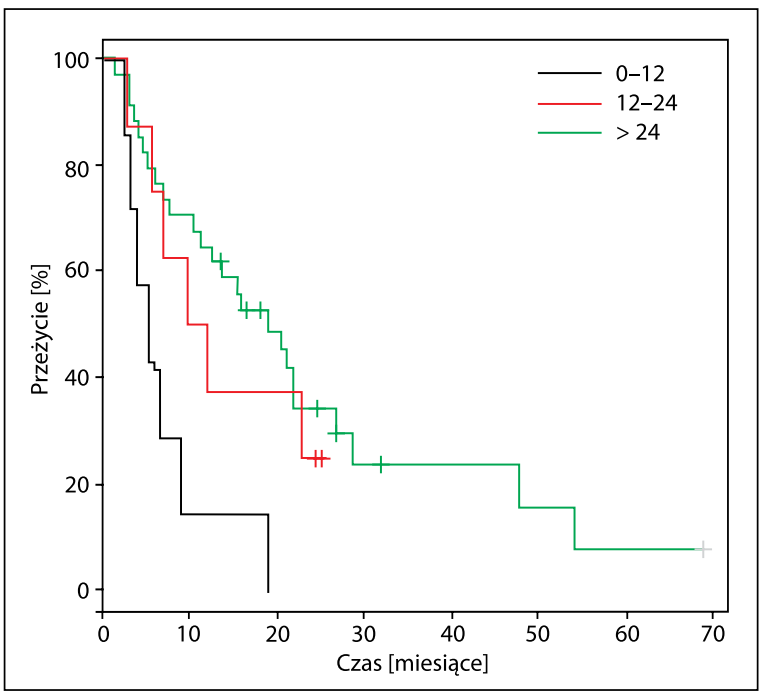

Rycina 4. OS w zależności od czasu (miesiące) rozpoznania pierwotnego choroby do rozpoczęcia leczenia trabektedyną

w badanej grupie. Stężenie hemoglobiny oraz aktywność LDH przy rozpoczęciu leczenia nie miały wpływu na wyniki leczenia. 34 pacjentów otrzymało kolejne linie leczenia po niepowodzeniu leczenia trabektedyną.

\section{Działania niepożądane leczenia}

Leczenie było dość dobrze tolerowane, jakąkolwiek jego toksyczność stwierdzono u 60\% pacjentów, w większości były to działania niepożądane w stopniu 1. lub 2. Nie stwierdzono żadnego zgonu spowodowanego toksycznością leczenia. Trzej pacjenci wymagali zakończenia leczenia z powodu toksyczności: u jednego stwierdzono wzrost poziomu kinazy kreatynowej w stopniu 4., u kolejnego — mielosupresję w stopniu 4. Ostatni z tych pacjentów 


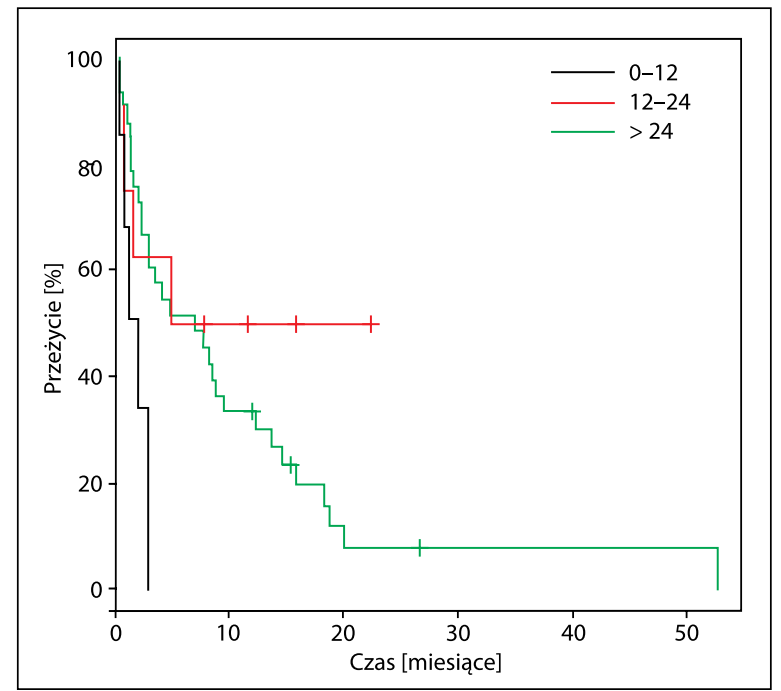

Rycina 5. PFS w zależności od czasu (miesiące) rozpoznania pierwotnego choroby do rozpoczęcia leczenia trabektedyną

wymagał zakończenia leczenia ze względu na nietolerowalne zmęczenie w stopniu 3. Troje pacjentów wymagało redukcji dawki leku ze względu na działania niepożądane. U trzech pacjentów doszło do nieznacznego wynaczynienia się leku. Najczęstszym działaniem niepożądanym była toksyczność hematologiczna, u 10 pacjentów stwierdzono leukopenię w stopniu 2. lub 3. 6 pacjentów wymagało odroczenia podania kolejnej dawki leku z powodu neutropenii 3. lub 4. stopnia. U 8 chorych stwierdzono małopłytkowość w stopniu 2. lub 3. Kolejnym działaniem niepożądanym charakterystycznym dla stosowania trabektedyny jest toksyczność wątrobowa leczenia, u 7 pacjentów stwierdzono podwyższony poziom gamma-glutamylotranspeptydazy w stopniu 2. lub 3., u 4 chorych doszło do podwyższenia poziomu fosfatazy zasadowej w stopniu 2. lub 3.

\section{Dyskusja}

Trabektedyna została zarejestrowana w Unii Europejskiej do stosowania u chorych z rozpoznaniem zaawansowanych/nieresekcyjnych MTM w 2007 roku. Od tego czasu lek ten ma już ustalone miejsce w leczeniu tej źle rokującej grupy pacjentów, a jego skuteczność potwierdzono w szeregu badań klinicznych na dużych grupach pacjentów. Wyniki prezentowane w tej pracy nie odbiegają od tych publikowanych w piśmiennictwie, co potwierdzają obserwacje z badań klinicznych w rutynowej praktyce.

W tabeli Il zestawiono wyniki uzyskane w badanej grupie chorych z tymi zaprezentowanymi w opublikowanych badaniach klinicznych drugiej fazy u pacjentów po niepowodzeniu wcześniejszych linii leczenia.

Podobne wyniki uzyskano u chorych leczonych trabektedyną w ramach tzw. rozszerzonego dostępu do leku, gdzie, jak wiadomo, włączani są mniej wyselekcjonowani pacjenci w porównaniu z badaniami klinicznymi. Do francuskiej analizy włączono dane 885 pacjentów leczonych trabektedyną po niepowodzeniu wcześniejszych linii chemioterapii opartych na doksorubicynie lub/i ifosfamidzie. W grupie tej $34 \%$ chorych otrzymało $\geq 6$ kursów trabektedyny (mediana podanych kursów wyniosła 4). Obiektywną odpowiedź na leczenie stwierdzono u 17\% chorych, zaś u 50\% uzyskano SD,

Tabela II. Porównanie wyników leczenia uzyskanych w badanej grupie chorych z zaprezentowanymi w opublikowanych badaniach klinicznych

\begin{tabular}{|c|c|c|c|c|c|}
\hline Badanie & Liczba chorych & Linia leczenia & Podtypy histologiczne & & \\
\hline KNTMKiCz & 50 & $\geq 2$ & $\begin{array}{l}\text { LMS } 20(40 \%) \\
\text { LPS } 30(60 \%)\end{array}$ & $\begin{array}{l}\text { PR } 4 \text { (8\%), SD } 23 \text { (46\%), } \\
\text { PD } 23(46 \%)\end{array}$ & $\begin{array}{l}\text { 6-miesięczny PFS 47\%; } \\
\text { mediana OS } 13 \text { miesiąca }\end{array}$ \\
\hline Yovine i wsp. [7] & 54 & $\geq 2$ & $\begin{array}{c}\text { LMS } 22(41 \%) \\
\text { LPS } 6(11 \%) \\
\text { GIST } 4(7 \%) \\
\text { Synovial sarcoma } 3(6 \%) \\
\text { MFH } 3(6 \%) \\
\text { Fibrosarcoma } 4(7 \%) \\
\text { Inne } 12(22 \%)\end{array}$ & $\begin{array}{l}\text { PR } 2(3,7 \%) \\
\text { SD } \geq 6 \text { miesięcy } 9(16,7 \%) \\
\text { SD } \geq 2 \leq 6 \text { miesięcy } \\
9(16,7 \%) \\
\text { PD } 28(51,9 \%)\end{array}$ & $\begin{array}{l}\text { 6-miesięczny PFS } \\
\text { 24,1\%; mediana OS } \\
\text { 12,8 miesiąca }\end{array}$ \\
\hline Le Cesne i wsp. [7] & 99 & $\geq 2$ & $\begin{array}{c}\text { LMS } 43(41 \%) \\
\text { LPS } 10(9,6 \%) \\
\text { Sarcoma synoviale } \\
18(17,3 \%) \\
\text { MFH } 6(5,7 \%) \\
\text { Fibrosarcoma } 1 \\
\text { Inne } 26\end{array}$ & $\begin{array}{l}\text { PR } 8(8,1 \%) \\
\text { SD } 45(45,5 \%) \\
\text { PD } 35(35,4 \%)\end{array}$ & $\begin{array}{l}\text { 6-miesięczny PFS 29\% } \\
\text { Mediana OS 9,2 miesiąca }\end{array}$ \\
\hline $\begin{array}{l}\text { Garcia-Carbonero } \\
\text { i wsp. [8] }\end{array}$ & 36 & $\geq 2$ & $\begin{array}{c}\text { LMS } 13(36 \%) \\
\text { LPS } 10(28 \%) \\
\text { MPNST } 2(6 \%) \\
\text { Synovial sarcoma } 6(17 \%) \\
\text { Inne } 5(13 \%)\end{array}$ & $\begin{array}{l}\text { CR } 1(3 \%) \\
\text { PR } 2(6 \%)\end{array}$ & $\begin{array}{l}\text { Mediana OS } \\
12,1 \text { miesiąca } \\
\text { OS po roku } 53,1 \% \\
\text { Mediana PFS } \\
1,7 \text { miesiąca }\end{array}$ \\
\hline
\end{tabular}

Skróty: KNTMKiCz - Klinika Nowotworów Tkanek Miękkich, Kości i Czerniaków, MFH (malignant fibrous histiocytoma) — złośliwy włóknisty mięsak histiocytarny, MPNST (malignant peripheral nerve sheath tumor) — złośliwy nowotwór osłonek nerwów obwodowych 
co daje kontrolę choroby u $67 \%$ leczonych. Mediana PFS wyniosła 4,4 miesiąca, zaś OS 12,2 miesiąca. Wśród pacjentów bez progresji choroby, u których kontynuowano leczenie, po sześciu kursach PFS wyniosło 11,7 miesiąca w porównaniu z 7,6 miesiąca w grupie chorych, u których zakończono leczenie po uzyskaniu przynajmniej SD po sześciu wlewach ( $p<0,003)$. Grupa leczona bez przerwy miała też istotnie dłuższe OS (24,9 miesiąca vs $16,9, \mathrm{p}<0,001)$ [13]. W badaniu II fazy potwierdzono lepsze rokowanie wśród chorych, u których stosowano leczenie trabektedyną nieprzerwanie do progresji choroby, w porównaniu z tymi chorymi bez progresji choroby, u których po sześciu kursach przerwano leczenie [16].

Szczególną skuteczność trabektedyna wykazuje w przypadku MLPS. Jest to drugi co do częstości występowania podtyp tłuszczakomięsaków i odpowiada za około 10\% rozpoznań wszystkich MTM [17]. Opublikowano wyniki retrospektywnych dwóch badań nad skutecznością trabektedyny tylko wśród chorych z tym rozpoznaniem. W pierwszym analizowano grupę 32 chorych, u których stosowano lek po niepowodzeniu wcześniejszych terapii. Odsetek obiektywnych odpowiedzi wyniósł 50\%, u dwóch osób stwierdzono CR, u 14 zaś PR. Stabilizację choroby stwierdzono u kolejnych 14 pacjentów. U 90\% chorych udało się uzyskać kontrolę choroby (CR+PR+SD). Mediana PFS dla całej grupy wyniosła 17 miesięcy. Po 6 miesiącach od rozpoczęcia leczenia $90 \%$ chorych było wolnych od progresji choroby [18]. W kolejnym badaniu nad grupą 51 chorych wyniki były dość podobne: stwierdzono 2 CR, 24 PR, w sumie $51 \%$ chorych miało obiektywną odpowiedź na leczenie. Mediana PFS wyniosła 14 miesięcy, a odsetek chorych wolnych od progresji choroby po pół roku od rozpoczęcia leczenia wyniósł 88\% [19]. Należy zwrócić uwagę na wysoki odsetek obiektywnych odpowiedzi na leczenie, rzadko spotykany przy zastosowaniu trabektedyny w pozostałych podtypach MTM.W analizowanej grupie rokowanie 13 pacjentów z rozpoznaniem MLPS także było wyraźnie lepsze w porównaniu z pozostałymi pacjentami. Po roku leczenia u $45 \%$ pacjentów nie stwierdzono progresji choroby, a po roku od rozpoczęcia leczenia żyło $69 \%$ z rozpoznaniem MLPS.

Trabektedyna jest lekiem dość dobrze tolerowanym. Najczęściej opisywanymi działaniami niepożądanymi jest mielosupresja i toksyczność wątrobowa [20]. Podobnie było w opisywanej grupie chorych, gdzie mimo tego, iż u większości pacjentów stwierdzono jakiekolwiek działanie niepożądane leczenia, to większość z nich była niskiego stopnia i w pełni odwracalna. Nie stwierdzono przypadków ciężkich działań niepożądanych, takich jak poważne wynaczynienia czy rabdomioliza [21, 22]. Co ważne, lek ten nie ma kumulacyjnej toksyczności, co jest ważne z uwagi na stosunkowo dużą grupę pacjentów, u których możliwe jest wielomiesięczne leczenie.

\section{Wnioski}

Prezentowane wyniki potwierdzają skuteczność i bezpieczeństwo stosowania trabektedyny u pacjentów z rozpoznaniem zaawansowanych/nieresekcyjnych L-mięsaków po niepowodzeniu wcześniejszych linii leczenia. W analizowanej grupie rokowanie jest podobne do tego prezentowanego we wcześniejszych publikacjach. Nie jest to lek, po którego działaniu można spodziewać się wysokiego odsetka obiektywnych odpowiedzi na leczenie, ale dzięki jego zastosowaniu u znaczącej liczby chorych udaje się uzyskać długotrwałą kontrolę choroby przy dość dobrej tolerancji leczenia i braku kumulacyjnej toksyczności leku. Lek ten jest szczególnie skuteczny u chorych z rozpoznaniem MLPS. Stosowanie trabktedyny będzie najpewniej coraz bardziej powszechne, szczególnie zważywszy na wyniki ostatnich randomizowanych badań, wskazujących na to, że jego skuteczność w przypadku części podtypów MTM nie jest istotnie mniejsza niż ta notowana przy tradycyjnych chemioterapeutykach, takich jak doksorubicyna [23, 24].

\section{Lista stosowanych skrótów:}

$\mathrm{Cl}$ (confidence interval) — przedział ufności

$\mathrm{CR}$ (complete remission) - całkowita remisja

CTC AE (common terminology criteria for adverse events) - powszechne kryteria stopniowania zdarzeń niepożądanych

GIST (gastrointestinal stromal tumors) - nowotwory podścieliskowe przewodu pokarmowego

HR (hazard ratio) — hazard względny

LMS (leiomyosarcoma) — mięśniakomięsak gładkokomórkowy

LPS (liposarcoma) — tłuszczakomięsak

MLPS (myxoid liposarcoma) — tłuszczakomięsak śluzowaty MFH (malignant fibrous histiocytoma) — złośliwy włóknisty mięsak histiocytarny

MPNST (malignant peripheral nerve sheath tumor) — złośliwy nowotwór osłonek nerwów obwodowych

MTM - mięsaki tkanek miękkich

NFZ — Narodowy Fundusz Zdrowia

OS (overall survival) — przeżycie całkowite

PFS (progression-free survival) — przeżycie wolne od progresji

PD (progressive disease) - progresja choroby

PR (partial remission) - częściowa remisja

SD (stable disease) — stabilizacja choroby

Konflikt interesów: nie zgłoszono

\section{Dr Hanna Koseła-Paterczyk}

Klinika Nowotworów Tkanek Miękkich, Kości i Czerniaków Centrum Onkologii — Instytut im. Marii Skłodowskiej-Curie ul. Roentgena 5, 02-781 Warszawa

e-mail:hanna.kosela@gmail.com

Otrzymano: 14 września 2015 r.

Przyjęto do druku: 14 października 2015 r. 


\section{Piśmiennictwo}

1. Clark MA, Fisher C, Judson I i wsp. Soft-tissue sarcomas in adults. NEngl J Med 2005; 353: 701-711.

2. http://onkologia.org.pl/k/epidemiologia/:

3. ESMO/European Sarcoma Network Working Group/. Soft tissue and visceral sarcomas: ESMO Clinical Practice Guidelines for diagnosis, treatment and follow-up. Ann Oncol 2014; 25 Suppl 3: iii102-12.

4. Judson I, Verweij J, Gelderblom H i wsp. Doxorubicin alone versus intensified doxorubicin plus ifosfamide for first-line treatment of advanced or metastatic soft-tissue sarcoma: a randomised controlled phase 3 trial. Lancet Oncol 2014; 15: 415-423.

5. D'Incalci M, Erba E, Damia G i wsp. Unique features of the mode of action of ET-743. Oncologist 2002; 7: 210-216.

6. Le Cesne A, Blay JY, Judson I i wsp. Phase II study of ET-743 in advanced soft tissue sarcomas: a European Organisation for the Research and Treatment of Cancer (EORTC) soft tissue and bone sarcoma group trial. J Clin Oncol 2005; 23: 576-584.

7. Yovine A, Riofrio M, Blay JY i wsp. Phase II study of ecteinascidin-743 in advanced pretreated soft tissue sarcoma patients. J Clin Oncol 2004; 22: 890-899.

8. Garcia-Carbonero R, Supko JG, Manola J i wsp. Phase II and pharmacokinetic study of ecteinascidin 743 in patients with progressive sarcomas of soft tissues refractory to chemotherapy. J Clin Oncol 2004; 22: $1480-1490$.

9. Demetri GD MM, Jones RJ i wsp. A randomized phase III study of trabectedin $(T)$ or dacarbazine (D) for the treatment of patients (pts) with advanced liposarcoma (LPS) or leiomyosarcoma (LMS). J Clin Oncol 2015; 33 suppl; abstr 10503.

10. Garcia-Carbonero R, Supko JG, Maki RG i wsp. Ecteinascidin-743 (ET-743) for chemotherapy-naive patients with advanced soft tissue sarcomas: multicenter phase II and pharmacokinetic study. J Clin Oncol 2005; 23: 5484-5492.

11. Samuels BL, Chawla S, Patel S i wsp. Clinical outcomes and safety with trabectedin therapy in patients with advanced soft tissue sarcomas following failure of prior chemotherapy: results of a worldwide expanded access program study. Ann Oncol 2013; 24: 1703-1709.

12. Blay JY, Italiano A, Ray-Coquard I i wsp. Long-term outcome and effect of maintenance therapy in patients with advanced sarcoma treated with trabectedin: an analysis of 181 patients of the French ATU compassionate use program. BMC Cancer 2013; 13: 64
13. Le Cesne A, Ray-Coquard I, Duffaud F i wsp. Trabectedin in patients with advanced soft tissue sarcoma: a retrospective national analysis of the French Sarcoma Group. Eur J Cancer 2015; 51: 742-750.

14. Demetri GD, Chawla SP, von Mehren M i wsp. Efficacy and safety of trabectedin in patients with advanced or metastatic liposarcoma or leiomyosarcoma after failure of prior anthracyclines and ifosfamide: results of a randomized phase II study of two different schedules. J Clin Oncol 2009; 27: 4188-4196.

15. Grosso F, Dileo P, Sanfilippo R i wsp. Steroid premedication markedly reduces liver and bone marrow toxicity of trabectedin in advanced sarcoma. Eur J Cancer 2006; 42: 1484-1490.

16. Le Cesne A, Blay JY, Domont J i wsp. Interruption versus continuation of trabectedin in patients with soft-tissue sarcoma (T-DIS): a randomised phase 2 trial. Lancet Oncol 2015; 16: 312-319.

17. Fiore M, Grosso F, Lo Vullo S i wsp. Myxoid/round cell and pleomorphic liposarcomas: prognostic factors and survival in a series of patients treated at a single institution. Cancer 2007; 109: 2522-2531.

18. Grosso F, Sanfilippo R, Virdis E i wsp. Trabectedin in myxoid liposarcomas (MLS): a long-term analysis of a single-institution series. Ann Oncol 2009; 20: 1439-1444.

19. Grosso F, Jones RL, Demetri GD i wsp. Efficacy of trabectedin (ecteinascidin-743) in advanced pretreated myxoid liposarcomas: a retrospective study. Lancet Oncol 2007; 8: 595-602.

20. Fayette J, Coquard IR, Alberti L i wsp. ET-743: a novel agent with activity in soft-tissue sarcomas. Curr Opin Oncol 2006; 18: 347-353.

21. Grosso F, D'Incalci M, Cartoafa M i wsp. A comprehensive safety analysis confirms rhabdomyolysis as an uncommon adverse reaction in patients treated with trabectedin. Cancer Chemother Pharmacol 2012; 69: 1557-1565.

22. Theman TA, Hartzell TL, Sinha I i wsp. Recognition of a new chemotherapeutic vesicant: trabectedin (ecteinascidin-743) extravasation with skin and soft tissue damage. J Clin Oncol 2009; 27: e198-200.

23. Bui-Nguyen B, Butrynski JE, Penel N i wsp. A phase llb multicentre study comparing the efficacy of trabectedin to doxorubicin in patients with advanced or metastatic untreated soft tissue sarcoma: the TRUSTS trial. Eur J Cancer 2015; 51: 1312-1320.

24. Blay JY, Leahy MG, Nguyen BB i wsp. Randomised phase III trial of trabectedin versus doxorubicin-based chemotherapy as first-line therapy in translocation-related sarcomas. Eur J Cancer 2014; 50: 1137-1147. 